М. О. Олійник

ORCID https://orcid.org/0000-0002-1327-5973

ResearcherID AAX-8046-2021

Scopus Author ID 57195737688

Ю. К. Сікало

ORCID https://orcid.org/0000-0001-6740-9378

ResearcherID T-3797-2019

Scopus Author ID 57215507505

I. В. Летік

ORCID https://orcid.org/0000-0002-5318-5817

ResearcherID AAX-8145-2021

Scopus Author ID 6507472482

Харківський національний медичний університет

\title{
ДОСВІД ДИСТАНЦЙНОГО НАВЧАННЯ СТУДЕНТІВ-ІНОЗЕМЦІВ НА КЛІНІЧНІЙ КАФЕДРІ МЕДИЧНОГО ЗАКЛАДУ ВИЩОЇ ОСВІТИ В УМОВАХ ПАНДЕМІЇ COVID-19
}

\author{
L. V. Zhuravlyova, M. O. Oliinyk, Yu. K. Sikalo, I. V. Letik \\ Kharkiv National Medical University \\ EXPERIENCE OF DISTANCE LEARNING FOR FOREIGN STUDENTS \\ AT THE CLINICAL DEPARTMENT OF THE MEDICAL INSTITUTION \\ OF HIGHER EDUCATION IN THE CONDITION OF THE COVID-19 \\ PANDEMIC
}

\begin{abstract}
Анотація. За час поширення коронавірусної інфекції у світі відбулася зміна звичного ритму життя із вимушеною необхідністю обмеження соціальної активності. При цьому гостро постала необхідність реалізації освітніх програм у повному обсязі для всіх навчальних закладів, у зв’язку з чим освітній процес було переведено на дистанційний формат навчання. Така форма навчання в сучасних умовах має ряд переваг, та, водночас, ряд педагогічних обмежень, що може вплинути на засвоєння матеріалу та якість освіти в цілому.

Метою нашого дослідження було вивчити ставлення іноземних студентів до онлайн-навчання та використання системи Moodle, оцінити якість сприйняття курсу і зручність у вивченні представленого матеріалу.

Студенти відповідали на блоки запитань щодо їх ставлення до досвіду застосування та участі в дистанційному навчанні, методів, що застосовували викладачі протягом онлайн-навчання, та ставлення до онлайн-навчання в цілому. На думку опитаних студентів, позитивними моментами у застосуванні дистанційного навчання є підвищення якості освітнього процесу, можливість студентів проявити самостійність та індивідуальність, доступність інформації в будь-який час, можливість урізноманітнити заняття та зробити їх цікавими, а також висока технологічність представленого матеріалу, об’єктивізація системи оцінювання знань студентів, сприяння інтенсивній розумовій діяльності викладача та студента, також сприйняття самоаналізу (рефлексії) своїх знань та досвіду.

3 огляду на наш досвід та отримані результати аналізу проведеного дослідження, ми вбачаємо перспективним розвиток інформаційно-освітнього середовища медичного університету з використанням дистанційних форм навчання та контролю знань за рахунок розширення інструментів персоніфікованого навчання, однак як додаткового методу, який не може замінити проведення практичних занять студентами за звичною формою навчання.
\end{abstract}

Ключові слова: освіта; дистанційне навчання; студенти; медичний заклад вищої освіти; Moodle. 
Abstract. There was a change in the usual rhythm of life with the forced need to limit social activity during the spread of coronavirus infection in the world. There was an urgent need to implement educational programs for all educational institutions, in connection with which the educational process was transferred to the distance learning format. This form of education in modern conditions has a number of advantages, and, at the same time, a number of limitations that can affect the assimilation of material and the quality of education in general.

The aim of our study was to examine the attitude of foreign students to online learning and the use of the Moodle system, to assess the quality of perception of the course and the convenience of studying the presented material.

Students answered blocks of questions about their attitudes to the experience of participation in distance learning, the methods that teachers used during online classes and attitudes of students to the online learning in general. Students noted the positive aspects of distance learning, such as improving the quality of the educational process, the ability of students to show independence and individuality, the availability of information at any time, the ability to diversify classes and make them interesting, as well as high manufacturability, more objective system assessment of students' knowledge, promotion of intensive mental activity of the teacher and the student, as well as the perception of self-analysis of knowledge and experience.

According to our experience and the results of the analysis of the study, we believe that the development of information and educational environment of medical university using distance learning and knowledge control by expanding the tools of personalized learning is promising, but as an additional method that cannot replace practical classes for students in the usual form of education.

Key words: education; distance learning; students; medical university; Moodle.

Вступ. У зв’язку зі стрімким поширенням коронавірусної хвороби (COVID-19) в Україні з березня 2020 р. було оголошено загальнонаціональний карантин із рекомендацією для всіх закладів вищої освіти щодо переведення освітнього процесу в дистанційний формат навчання. При цьому всі заклади вищої освіти (3ВО) повинні були забезпечити реалізацію освітніх програм у повному обсязі.

Питання про зміну формату навчального процесу в медичних університетах постало особливо гостро, оскільки потребувало швидкого пошуку альтернативних та ефективних методик навчання в умовах обмеженого доступу до клінічних баз, де проходять практичні заняття і відпрацювання практичних навичок за участі пацієнтів лікарняних установ.

У зв'язку з цим перед нами постало завдання максимально задіяти технології дистанційної освіти.

На момент оголошення карантину викладачі кафедри внутрішньої медицини № 3 та ендокринології ХНМУ вже активно проходили навчання по розробці і впровадженню в освітній процес системи Moodle (Modular Object-Oriented Dynamic Learning Environment - модульне об'єктно-орієнтоване динамічне навчальне середовище), яке було організоване Навчально-науковим інститутом якості освіти XНMУ. Moodle - це сучасне програмне забезпечення, що дозволяє викладачеві і студенту ефективно взаємодіяти он-лайн. Moodle була створена в Технологічному австралійському університеті і від самого початку позиціонувалася як відкрита, проста в установці і безкоштовна освітня платформа, в якій все чітко структуроване, немає нічого зайвого $[2,6]$.

Основною метою платформи є організація віддаленого навчання, де кожен бажаючий може налаштовувати систему під себе і вносити свої доповнення. Це інноваційна модель отримання освіти в режимі online з будь-якого зручного місця та на будь-якому пристрої з доступом до мережі «Інтернет». Водночас платформа дозволяє максимально зберегти традиційні цінності очного навчання.

Організація навчального процесу на кафедрі була проведена в найкоротші терміни завдяки активній позиції керівництва університету щодо впровадження Moodle, як офіційної платформи дистанційного навчання ХНМУ, із обов'язковою реєстрацією всіх студентів та викладачів.

Водночас викладачі кафедри активно займалися створенням курсів для забезпечення дистанційного навчання студентів. Треба зазначити, що наша кафедра дуже відповідально ставиться до педагогічного процесу. Незважаючи на те, що ми викладаємо клінічні дисципліни, 15 викладачів нашої кафедри мають ступінь магістра із педагогіки вищої школи, тому новітні технології та методи навчання активно впроваджуються в педагогічний процес. Крім того, ми вже мали деякий досвід використання дистанційних платформ, протягом 10 років наша кафедра має власний сайт кафедри, на якому ми розміщуємо матеріали для дистанційного навчання студентів, а також різноманітні онлайн-тренажери.

У рамках кафедральної директорії Moodle ХНМУ було створено дистанційні курси відповідно до навчальної програми із різнорідним наповненням записано відеолекції, створено презентації лекцій, матеріали для теоретичної підготовки та контролю знань, самостійної роботи, завантажено матеріали для наочної підготовки, електронні підручники, методичні посібники, тестові завдання, створено базу клінічних кейсів, введено активні посилання на першоджерела міжнародних рекомендацій 3 діагностики і лікування ряду захворювань, та інші матеріали для навчання поза університетом. Крім того, студенти мали змогу використовувати ресурси 
власного сайту кафедри http://vnmed3.kharkiv.ua/, який вже тривалий час є помічником студентів у підготовці до занять.

Перші дні дистанційного навчання викликали деяке занепокоєння щодо психолого-педагогічної адаптації студентів до дистанційної освіти, враховуючи особливості викладання клінічних дисциплін, тобто специфіку предмета [1]. Однаково, як у студентів, так і викладачів, виникали деякі труднощі, пов’язані з відсутнім попереднім досвідом використання дистанційних форматів навчання і проведення занять. Крім того, усім учасникам знадобився деякий час для адаптації до зміни активного об’єкта навчання, оскільки при дистанційному форматі обмежується особистий контакт між студентом і викладачем. Зрештою, вже після другого тижня початку онлайн-навчання взаємодія між викладачами та студентами покращилася та дала позитивні результати.

Варто зазначити, що процес дистанційної освіти досить цікавий, особливо для тих, хто не уявляє свого життя без різноманітних гаджетів. Використання спеціальних платформ зі структурованим навчальним матеріалом у вигляді модулів, що включають методичні рекомендації з теми заняття, наочні i теоретичні ресурси, пояснення до практичних завдань, посилання на необхідну літературу, допомагає в засвоєнні матеріалу. Викладачі кафедри мають можливість постійно контролювати діяльність студентів і знаходяться з ними на зв’ язку [7].

Використання платформи Moodle в освітньому процесі дозволяє організувати досить якісне навчання на відстані, шляхом створення різнорідних веб-курсів і наповнення їх навчальним контентом. Елементами онлайн-курсів є різні інтерактивні завдання, текстові сторінки, словники, посилання, файли і багато іншого [3, 4].

Програма виявилася досить простою у використанні: зручний інтерфейс, мобільність та можливість змінювати налаштування під себе роблять її доступною і зрозумілою всім користувачам. Крім того, зручною є опція збереження в системі всіх студентських самостійних робіт, результатів складання тестів та контрольних робіт, до яких у разі потреби можна повернутися. Оцінювання $є$ максимально об’єктивним, оскільки більшою мірою проходить автоматично.

Отже, з метою вивчення ставлення англомовних іноземних студентів, які навчаються на кафедрі внутрішньої медицини № 3 та ендокринології ХНМУ, до дистанційного навчання та використання платформи Moodle, ми провели анонімне анкетування за спеціально створеною анкетою наприкінці навчального семестру.

Мета дослідження - вивчити ставлення іноземних студентів до онлайн-навчання та використання системи Moodle, оцінити якість сприйняття курсу і зручність у вивченні представленого матеріалу.

Методи дослідження. Протягом весняного семестру 2020 р. заняття на кафедрі проводились у змішаному форматі, що передбачало поєднання навчання в режимі реального часу (онлайн-вебінари) та за допомогою освітньої платформи дистанційного навчання Moodle (без взаємодії в реальному часі). Наприкінці навчального року було проведено анкетування студентів-іноземців, загалом 252 студентів VI та VII факультетів Навчально-наукового інституту підготовки іноземних громадян ХНМУ, щодо їх ставлення та ступеня задоволення навчальним процесом із застосуванням освітніх дистанційних технологій. Було створено анкету, яка налічувала 25 питань із різних аспектів дистанційного навчання, а також були включені питання щодо ставлення студентів до дистанційного навчання. Методом дослідження стало проведення анонімного анкетування в онлайн-платформі Moodle через використання ресурсу «зворотний зв’язок». Опитування проводили через 3 місяці після початку карантинних обмежень та запровадження дистанційного навчання, перед проведенням диференційного заліку. Аналіз результатів проводили з використанням методів описової статистики.

Результати дослідження. Початкові питання стосувалися попереднього досвіду використання онлайн-навчання та участі у вебінарах, які студенти могли мати до запровадження карантинних обмежень (рис. 1-3).

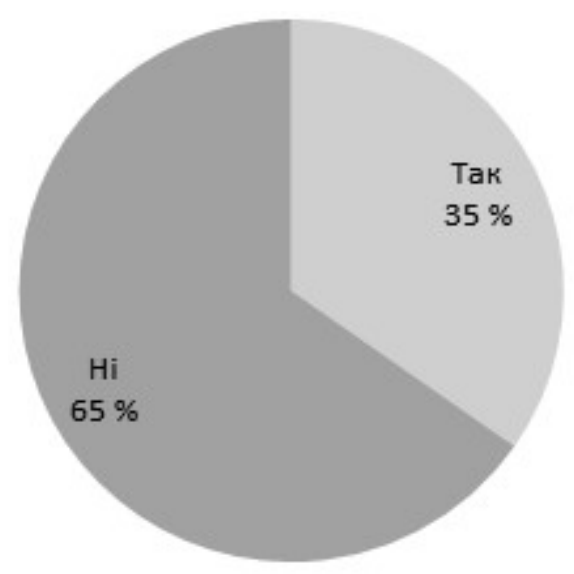

Рис. 1. Чи був у Вас попередній досвід проходження дистанційного навчання (курси, вебінари тощо)? 


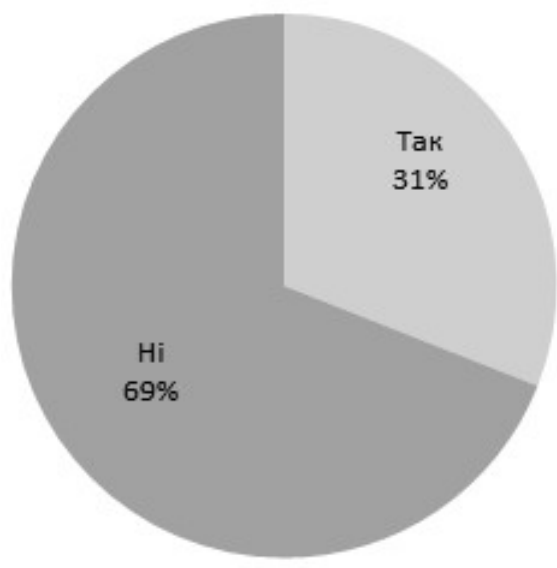

Рис. 2. Чи був у Вас попередній досвід проведення вебінарів/або Ви були доповідачем на телеконференціях?

Як бачимо $з$ наведених діаграм, більшість студентів не мала досвіду як дистанційного навчання, так і участі в заходах за допомогою дистанційних платформ.

Отриманий досвід онлайн-навчання був дуже цікавим для студентів, це було щось нове та незвичне, тому зацікавленість студентів у проведенні дистанційних занять була досить високою, 33 \% студентів проявляли максимальну зацікавленість та $31 \%$ - середню (рис. 4).

Використання «активних методів навчання» $\epsilon$ невід'ємною складовою сучасної медичної освіти, що відображає загальну тенденцію відходу від традиційних догматичних пасивних методів на-

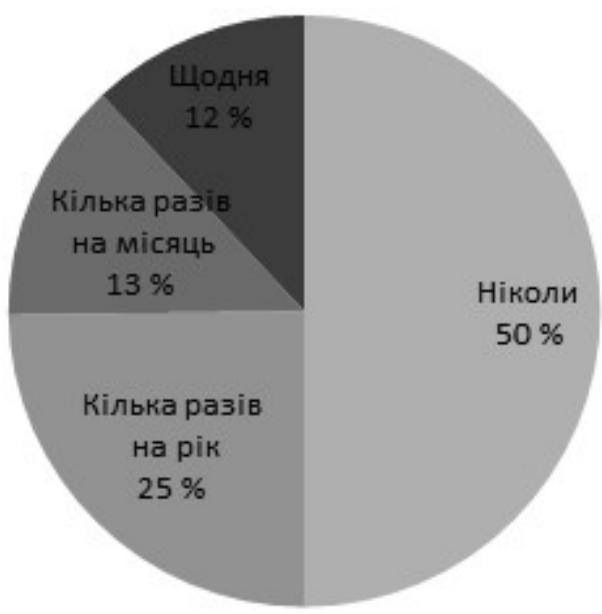

Рис. 3. Як часто раніше Ви брали участь у вебінарах як слухач?

вчання (в яких викладач виступає транслятором знань) до активних методів, які повинні полегшити студентам сприйняття отримання інформації через власний досвід. Активні, а з часом й інтерактивні методи навчання, широко та протягом тривалого часу впроваджені в педагогічний процес нашої кафедри, а саме: рішення клінічних завдань та клінічних кейсів, виконання мануальних дій на моделях або пацієнтах (навички пальпації, перкусії, аускультації тощо), навчальні рольові ігри, квести, науково-дослідна робота студентів, складання навчальної історії хвороби. Аналіз методів навчання, які використовували викладачі на нашій кафедрі, представлено на рисунках 5 та 6.
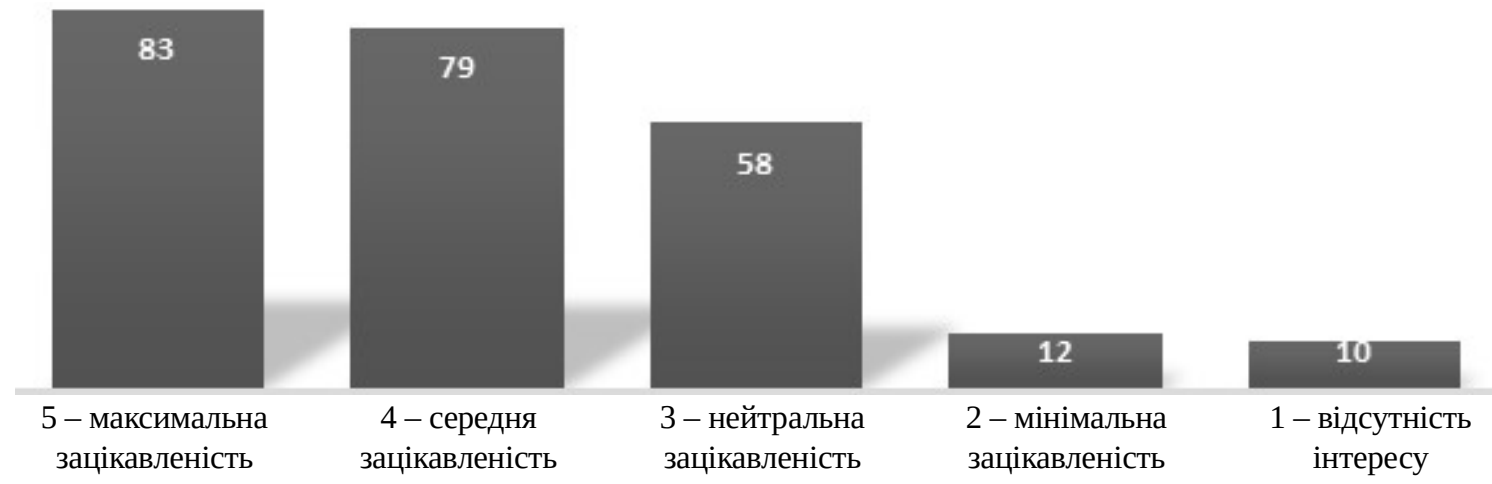

Рис. 4. Як би Ви оцінили свою зацікавленість у використанні в навчальному процесі дистанційних форм навчання?

При порівнянні методів навчання, які використовували викладачі в процесі навчання до карантину та після його впровадження, істотну перевагу отримали пасивні методики, а саме: лекція-монолог, читання, опитування та демонстрація.

Треба зазначити, що можливості платформи Moodle досить широкі. Так, система дає змогу проводити відеоконференції в Moodle на плат- формі BigBlueButton - вона підтримує наявність декількох аудіодоріжок й обмін відео, можливість показу презентацій, документів Microsoft Office та OpenOffice, зображень, PDF документів. Також підтримуються розширені можливості дошки покажчик, масштабування і малювання, доступ до робочого столу. Для зворотного зв'язку зі слухачами веб-конференції існують публічні та приватні 


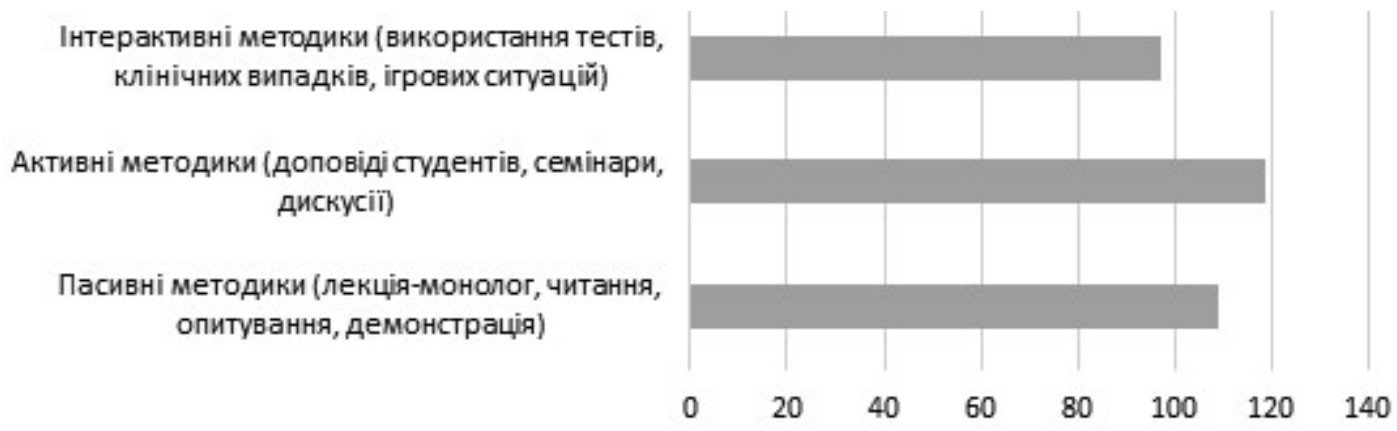

Рис. 5. Які методи навчання використовували викладачі в процесі навчання на нашій кафедрі до карантину? (Можна відзначити декілька варіантів.)

\author{
Інтерактивні методики (використання тестів, \\ клінічних випадків, ігрових ситуацій) \\ Активні методики (доповіді студентів, семінари, \\ дискусії) \\ Пасивні методики (лекція-монолог, читання, \\ опитування, демонстрація)
}

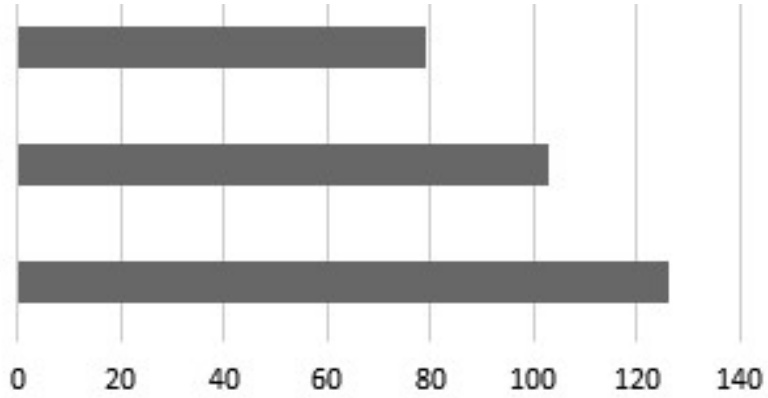

Рис. 6. Які методи навчання використовували викладачі в процесі навчання на нашій кафедрі під час карантину? чати. Користувач може увійти в конференцію або як глядач або як модератор. Як глядач, користувач може приєднатися до голосової конференції, використовувати web-камеру, підняти руку (попросити слово) і спілкуватися з іншими учасниками зустрічі. В ролі модератора користувач має можливість відключити/включити мікрофон будь-якого глядача, видалити будь-якого глядача з веб-конференції, а також передати слово будь-якому глядачеві для виступу (зробити будь-якого користувача провідним). Модератор може завантажувати презентації, документи, використовувати дошку. Також цікавою $\epsilon$ можливість проведення тестування протягом заняття з миттєвим отриманням результатів викладачем, та можливістю демонстрації їх на екрані [5].

Ми досить широко почали використовувати цю можливість під час заняття та запитали у студентів їх ставлення щодо використання тестування протягом занять. Білышість студентів позитивно оцінила використання тестів протягом занять (77\%) (рис. 7).

Наступні питання стосувались уважності студентів на лекціях та впливу використання тестів протягом них (рис. 8, 9).

Загалом, студенти досить уважно слухали лекції. Встановлено, що загальна кількість студентів із рівнем уваги від 70 до 100 \% була однаковою (63 \%) як при відсутності тестування, так і при його проведенні. Водночас співвідношення студентів між групами із рівнем уваги 70-80 \% та 90-100\%

збільшилось у бік покращення уваги при проведенні тестування. Що стосується студентів, які були менш уважними на початку, то ступінь їх уваги залишився майже без змін, та навіть дещо зменшився.

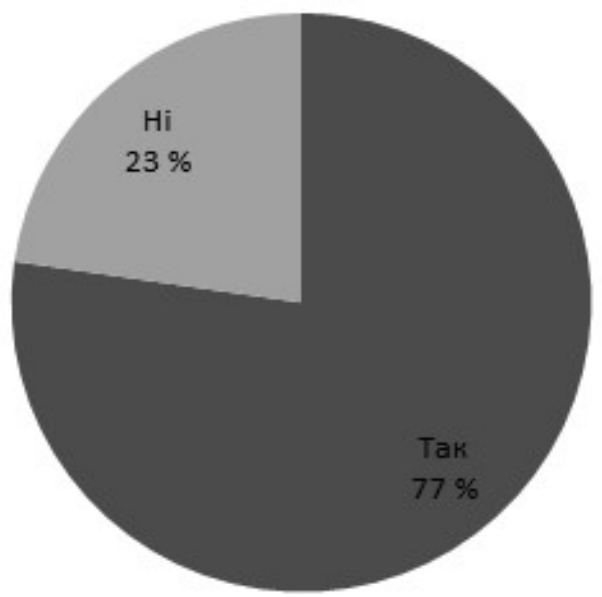

Рис. 7. Чи вважаєте Ви корисним використання тестування під час проведення заняття?

Враховуючи можливості платформи Moodle, студенти мають змогу виконувати додаткові завдання та відправляти виконану роботу викладачу на перевірку он-лайн, включаючи завантаження файлів будь-якого обсягу, типу і кількості (Word документ, Power Point, відеокліп тощо). Нам було цікаво дізнатися, в підготовці якого контенту їм самим було б цікаво взяти участь. Більшість студентів обрала складання клінічного випадку в Power Point, а саме 


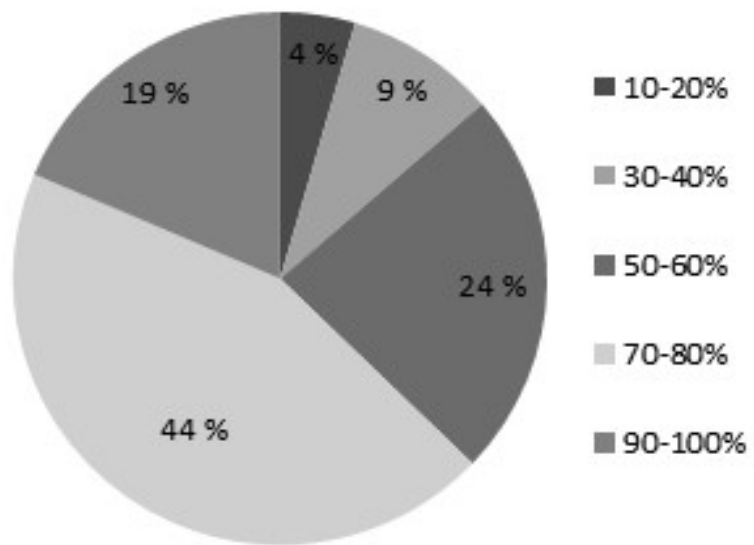

Рис. 8. Наскільки уважно Ви слухали онлайн-лекції без використання тестів під час лекції?

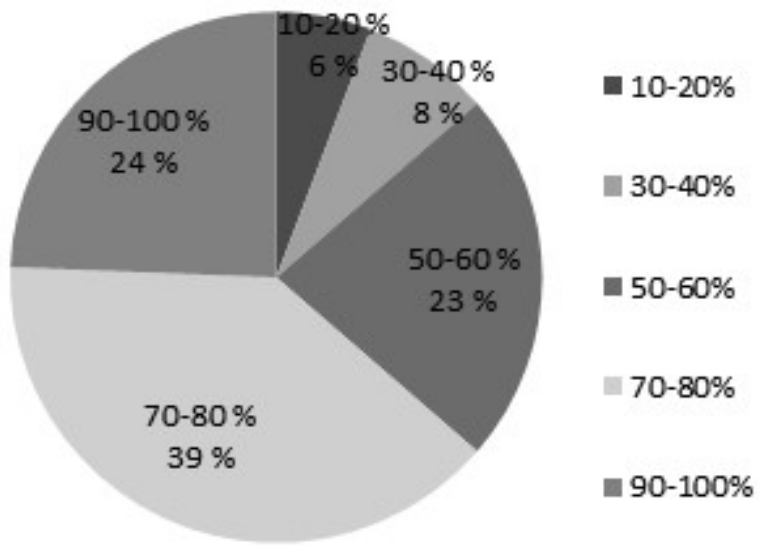

Рис. 9. Наскільки уважно Ви слухали онлайн-лекції з використанням тестування під час лекції?

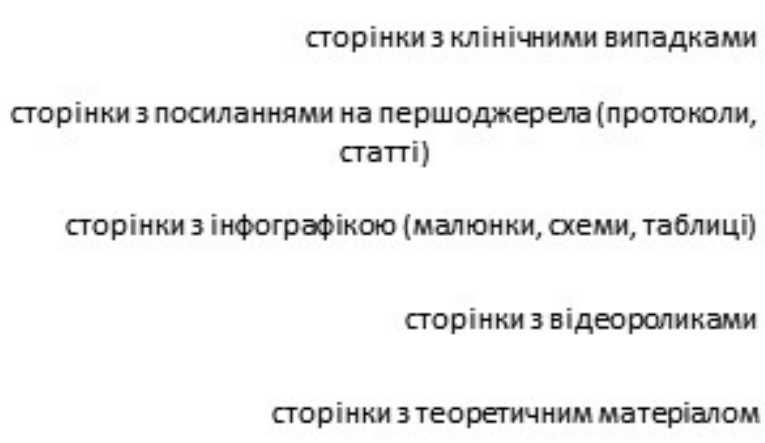

сторінки з теоретичним матеріалом
34,30 \% опитаних, наступним було складання тестів (28,1 \%), складання клінічного завдання з множинною відповіддю в Power Point (27,69 \%) та проведення запису коротких відеороликів та скрінкастів (24,79 \%). Знайшлись і такі студенти (13,64 \%), для кого не було цікавим брати участь у приготуванні будь-якого контенту.

Дещо іншими були результати аналізу ставлення студентів до виконання додаткових завдань, які викликали інтерес і сприяли поліпшенню навчання дисципліни «Внутрішня медицина». Так, найбільш цікавим було рішення ситуаційних завдань, 41,34 \% студентів висловилися позитивно щодо цього виду активностей. Наступними були проходження тестів (35,95\%), складання клінічного випадку за темою заняття (33,88 \%), та найменш цікавим було приготування тестів до теми (25,62 \% опитаних).

Треба зауважити, що система Moodle дуже мобільна, вона дозволяє викладачу створювати всілякі веб-курси і наповнювати їх різноманітним навчальним контентом. Елементами онлайн-курсів виступають різні інтерактивні завдання, текстові сторінки, словники, посилання, файли і багато іншого. Залежно від інтересу та потреб викладач має змогу корегувати та змінювати контент під аудиторію, тому для нас було цікаво знати, який контент у дистанційному курсі викликає інтерес у студентівіноземців та сприяє покращенню вивчення дисципліни «Внутрішня медицина» (рис. 10).

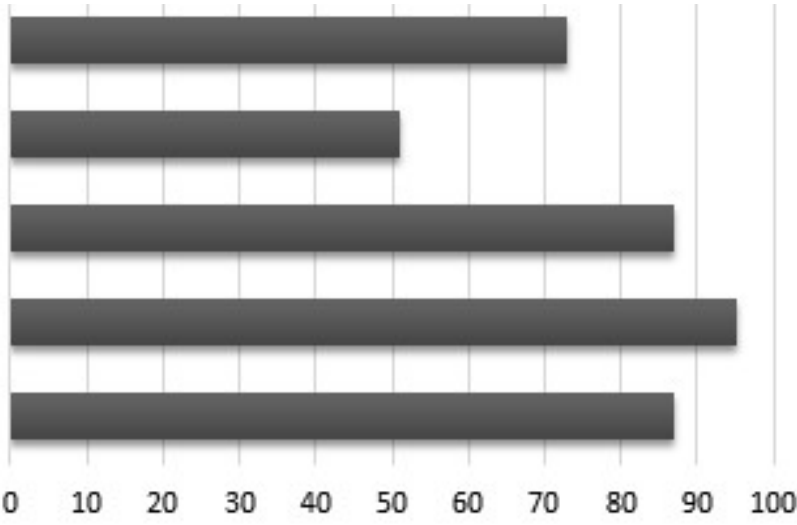

Рис. 10. Які види активностей у дистанційному курсі викликали у Вас інтерес і сприяли поліпшенню вивчення дисципліни «Внутрішня медицина»?

Так, найбільш цікавим контентом для студентів виявилися сторінки з відеороликами (37,69 \%), на другому місці - сторінки з інфографікою та теоретичним матеріалом (34,52 \%), дещо менший інтерес виявився до сторінок із клінічними випадками (28,96 \%). Найменш цікавим для студентів був матеріал, який містив сторінки із посиланнями на першоджерела (20,23 \%), а саме статті, клінічні протоколи тощо. Треба зазначити, що студенти мали змогу обрати декілька варіантів відповідей.

Як було зазначено вище, під час заняття викладач має можливість передати слово будь-якому студенту для виступу, та в якості ведучого студент також має змогу завантажувати презентації, 
документи, використовувати дошку. Зазвичай студенти досить позитивно сприймають можливість підготувати додатковий контент до заняття, тому ми запитали студентів щодо їх інтересу до виконання додаткових завдань при підготовці до занять (рис. 11).

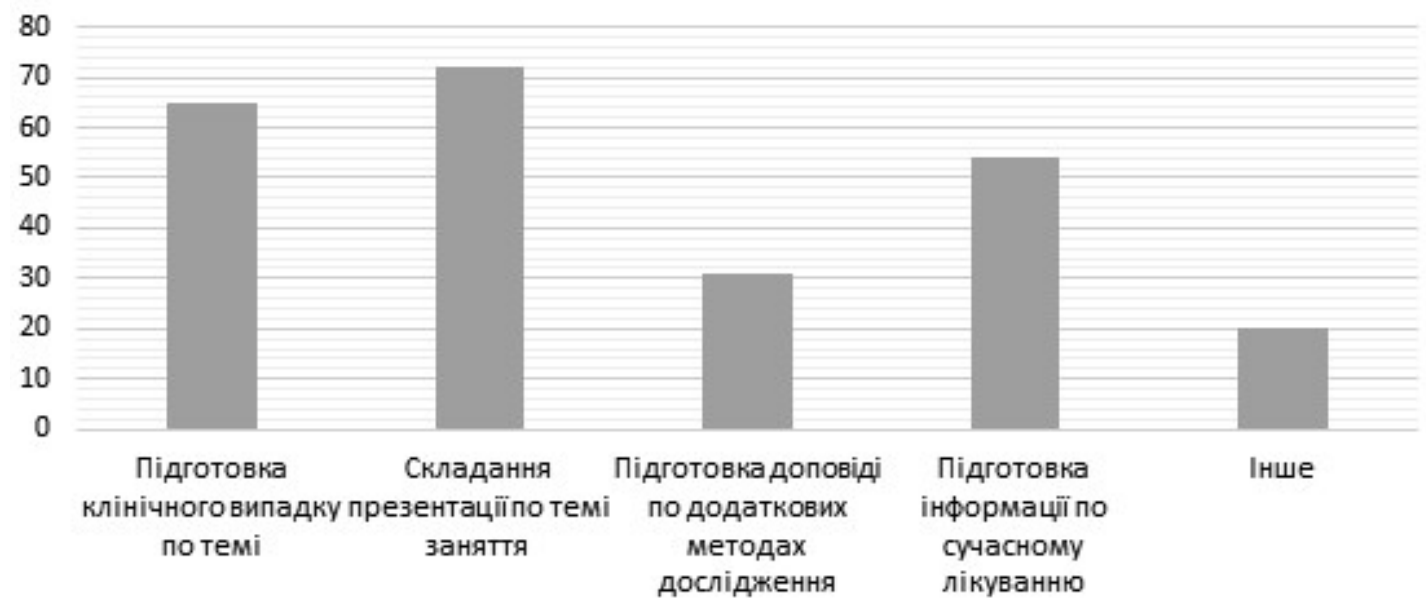

Рис. 11. Які додаткові завдання Вам було б цікаво виконувати в процесі підготовки до заняття?

Серед додаткових завдань найбільш цікавими для студентів були складання презентації до теми заняття (72 \%), підготовка клінічного випадку (65 \%) або підготовка інформації по сучасному лікуванню (54 \%). Значно менший інтерес стосувався підготовки матеріалів про додаткові методи дослідження тієї чи іншої патології (31%). Нас також цікавила особиста думка студентів, тому вони мали змогу обрати опцію «інше» та висловити свої уподобання, серед яких переважали бажання по створенню відеороликів або приготування стислого конспекту 3 теми заняття.

Наступний блок питань стосувався ставлення студентів до дистанційної платформи та онлайнзанять взагалі. Так, більшість студентів позитивно оцінила можливість використання дистанційної платформи, що відзначилось як на підвищенні рівня підготовки з предмета (66,53 \%), так і в активному залученні студентів до аналітичного процесу (67,77 \%). Також студенти відзначили, що дистанційний формат навчання забезпечив активну взаємодію всіх учасників освітнього процесу (70,66 \%), сформував позитивну мотивацію навчання (71,90\%). 74,79 \% студентів відмітили сприяння дистанційного навчання оптимізації навчального процесу, а 75,62 \% опитаних сприймають дистанційне навчання як перспективний напрямок в освітньому процесі.

Цікавою була думка студентів щодо впровадженої дистанційної платформи Moodle в нашому 3ВО та часу, який має бути виділений на навчання в онлайн-середовищі (рис. 12).

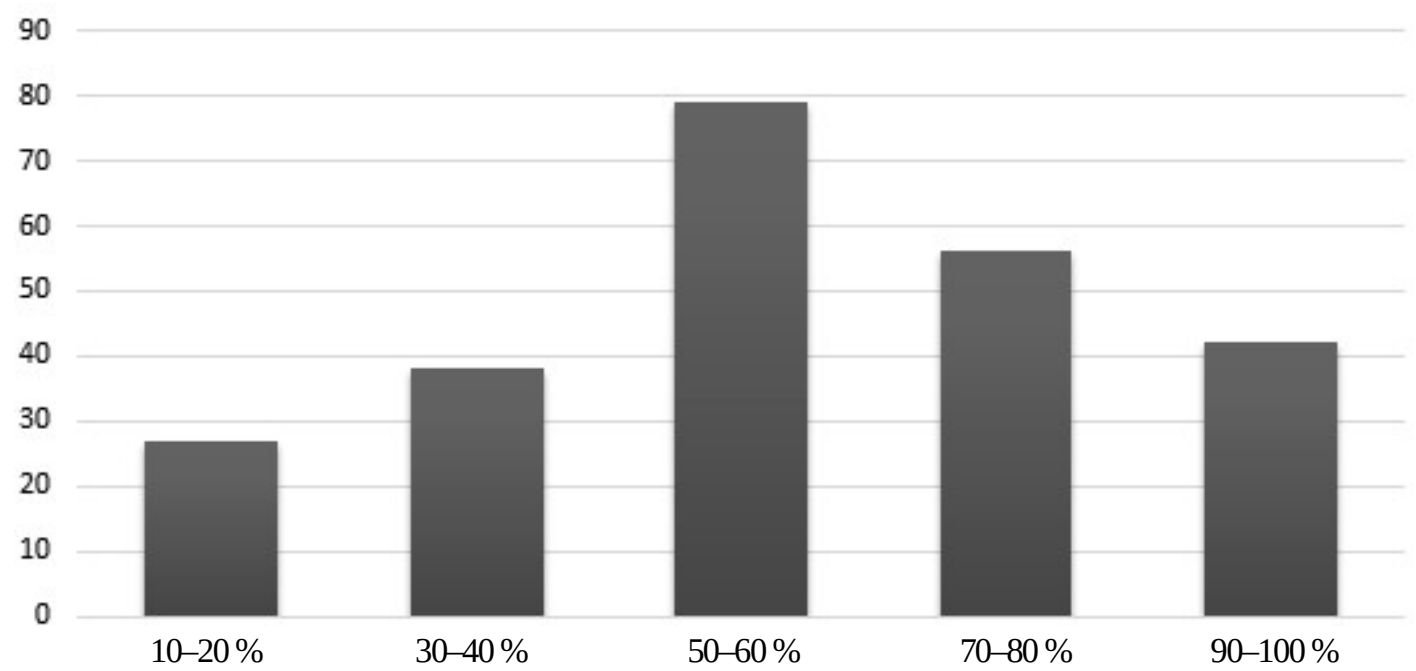

Рис. 12. Як Ви думаєте, який відсоток занять у медичному ЗВО повинен бути з використанням дистанційної платформи? 
31,34 \% опитаних студентів-іноземців вважають, що відсоток занять із використанням дистанційної платформи повинен становити від 50 до $60 \%$, 22,2 \% студентів обрали діапазон у 70-80 \% занять, $15 \%$ студентів вважають що від 30-40 \% та 10,7 \% опитаних обрали 10-20\%. Однак для нас було несподіваним, що близько 16 \% студентів вважають, що від 90-100 \% занять повинні бути із використанням дистанційної платформи.

Що стосується ставлення студентів до використання викладачем у процесі навчання дистанційної платформи, воно більшою мірою виявилось позитивним. Швидше негативне обрали лише 2 \% студентів та за цілковито негативне ставлення не висловився жоден студент (рис. 13).

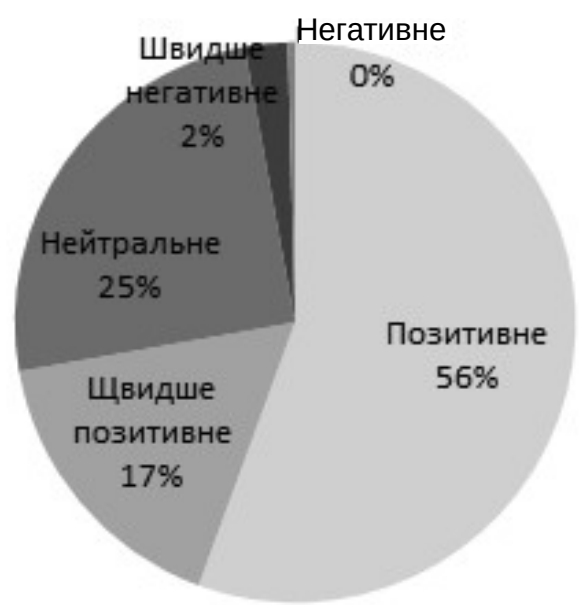

Рис. 13. Ваше ставлення до використання викладачем у процесі навчання дистанційного навчання?

На думку опитаних студентів, позитивним та ефективним у застосуванні дистанційного навчання $є$ підвищення якості освітнього процесу (44,63 \%), наявність можливості студентам проявити самостійність (40,50 \%) та індивідуальність (18,18 \%), доступність інформації в будь-який час (39,26 \%), дозволяють урізноманітнити заняття та зробити їх цікавими (24,38 \%), відмітили студенти також і високу технологічність представленого матеріалу - аудіо-, відеоматеріалу (23,55 \%) та підвищення активності пізнавального процесу (22,73 \%), об'єктивізацію системи оцінки знань студентів (19,42 \%), сприяння інтенсивній розумовій діяльності викладача та студента (18,18 \%), також сприйняття самоаналізу (рефлексії) своїх знань та досвіду (14,88 \%).

Серед недоліків системи студенти відзначили малу залученість студентів у заняття (31,40 \%), відсутність можливості безпосереднього вирішення завдань професійного спрямування (28,1 \%), відсутність швидкого зворотного зв' язку від викладача $(11,98 \%)$. Деякі студенти не побачили переваг від інших методів навчання (18,18 \%), а для певної кількості студентів недоліками є необхідність вміння користуватися комп’ютером (20,25 \%) та потрібність доступу до мережі «Інтернет» (33,47 \%).

Висновки та перспективи подальших досліджень. Наразі дистанційне навчання студентів медичного закладу вищої освіти в умовах особливої епідеміологічної ситуації, пандемії коронавірусної хвороби, $є$ досить великою стресовою ситуацією, як для самих студентів, так і для викладачів. Треба зауважити, що невід'ємною частиною процесу інтенсифікації навчання в рамках змішаного навчання на клінічних кафедрах $є$ поєднання теоретичного матеріалу дисципліни з практичною діяльністю. На жаль, в умовах карантину, виконання практичної частини заняття неможливе, тому використання сучасних інформаційно-освітніх технологій може сприяти підвищенню ефективності навчального процесу; забезпечує розвиток когнітивної діяльності студентів, формує їх зацікавленість станом світової науки та проведенням самостійних наукових досліджень.

Медична освіта - особлива галузь, яка потребує значних зусиль і витрат часу з боку учнів, більша частина якого відводиться на освоєння практичних навичок, тому можливості електронного навчання використовуються з обмеженнями. Так, студенти відзначають досить високу зацікавленість доданим матеріалом, також досвід роботи з іноземними студентами дозволяє зробити висновок про те, що дидактичний матеріал, відібраний для студентівмедиків при дистанційній формі навчання, повинен бути цікавим і корисним. Але тільки за умови гарної мотивації слухачів. Також варто відзначити, що спілкування через Інтернет, яким би частим i наближеним до реальності воно не було, все ж не дозволяє повністю замінити емоційний контакт із викладачем під час традиційних занять.

3 огляду на це, вбачаємо перспективним напрямком розвиток інформаційно-освітнього середовища медичного університету, використання дистанційних форм навчання та контролю знань, за рахунок розширення інструментів персоніфікованого навчання, однак як додаткового методу, який не може замінити проведення практичних занять студентами за звичною формою навчання. 


\section{Список літератури}

1. Авачева Т. Г. Развитие дистанционных образовательных технологий для формирования информационно-образовательной среды в медицинском вузе / Т. Г. Авачева, Э. А. Кадырова // Современные технологии в науке и образовании - СТНО-2018 : сб. тр. Междунар. науч.-техн. форума : в 10 т. Т. 9 / под общ. ред. О. В. Миловзорова. - Рязань : Рязан. гос. радиотехн. ун-т, 2018. - С. 18-22.

2. Авдєєв О. В. Використання дистанційної системи MOODLE для оптимізації навчального процесу у вищій школі / О. В. Авдєєв // Медична освіта. - 2015. - № 1. https://doi.org/10.11603/me.v0i1.4156.

3. Дронова Е. Н. Организационно-педагогические условия эффективного использования системы дистанционного обучения в учебном процессе магистратуры в педагогическом вузе / Е. Н. Дронова // Информатика и образование. - 2017. - Т. 7. - С. 51-57.

\section{References}

1. Avacheva, T.G., \& Kadyrova, E.A. (2018). Razvitiye distantsionnykh obrazovatelnykh tekhnologiy dlya formirovaniya informatsionno-obrazovatelnoy sredy $\mathrm{v}$ meditsinskom vuze [Development of distance educational technologies for the formation of an information and educational environment in a medical university]. Coll. of Works International Scientific and Technical Forum: Sovremennyye tekhnologii v nauke i obrazovanii - Modern Technologies in Science and Education. Milovzorov O. V. Eds. Ryazan: Ryazan. Gos. Radiotekhn. Un-t [in Russian].

2. Avdeev, O.V. (2015). Vykorystannya dystantsiynoyi systemy moodle dlya optymizatsiyi navchalnoho protsesu u vyshchiy shkoli [The use of remote moodle system to optimize the educational process in higher education]. Medychna osvita - Medical Education, 1. https://doi. org/10.11603/me.v0i1.4156 [in Ukrainian].

3. Dronova, E.N. (2017). Organizatsionno-pedagogicheskiye usloviya effektivnogo ispolzovaniya sistemy distantsionnogo obucheniya Moodle v uchebnom protsesse magistratury $\mathrm{v}$ pedagogicheskom vuze [Organizational and pedagogical conditions for the effective use of the Moodle distance learning system in the educational process of magistracy in a pedagogical university]. Informatika i obrazovanie - Informatics and Education, 7, 51-57 [in Russian].
4. Застосування компетентнісного підходу при організації очно-заочного навчання на різних етапах підготовки лікарів / О. С. Никоненко, С. Д. Шаповал, С. М. Дмитрієва, Т. О. Грицун // Медична освіта. 2019. - № 3. - C. 55-58. https://doi.org/10.11603/me.24145998.2019.3.10125.

5. Обзор интерфейса BigBlueButton. - Режим доступа : bigbluebutton.org.

6. Офіційний сайт Moodle. - Режим доступу : https:// www.moodle.ro/.

7. Слепцова Л. Н. Внедрение системы дистанционного обучения для работы со студентами с индивидуальным графиком обучения как ключевое направление развития образовательных учреждений профессионального образования / Л. Н. Слепцова, Е. В. Николаев // Педагогические науки. - 2017. - № 4 (25). - С. 110-112.
4. Nikonenko, O.S., Shapoval, S.D., Dmitrieva, S.M., \& Gritsun, T.O. (2019). Zastosuvannya kompetentnisnoho pidkhodu pry orhanizatsiyi ochno-zaochnoho navchannya na riznykh etapakh pidhotovky likariv [Application of the competence approach at the organization of full-time and correspondence training at different stages of preparation of doctors]. Medychna osvita - Medical Education, 3, 5558. https://doi.org/10.11603/me.2414-5998.2019.3.10125 [in Ukrainian].

5. Overview of the BigBlueButton interface. Retrieved from: bigbluebutton.org.

6. Website: Moodle. Retrieved from: https://www.moodle. ro.

7. Sleptsova, L.N., \& Nikolayev, Ye.V. (2017). Vnedreniye sistemy distantsionnogo obucheniya dlya raboty so studentami s individualnym grafikom obucheniya kak klyuchevoye napravleniye razvitiya obrazovatelnykh uchrezhdeniy professionalnogo obrazovaniya [Implementation of a distance learning system for working with students with an individual training schedule as a key direction in the development of educational institutions of vocational education]. Pedagogicheskiye nauki - Pedagogical Sciences, 4 (25), 110112 [in Russian]. 